\title{
Cost efficiency and risk as determinants of market share in banking: Evidence from the old and new eu member and candidate countries*
}

\author{
Bashkim Nurboja ${ }^{1}$, Marko Košak ${ }^{2}$
}

\begin{abstract}
In this study we investigate how cost efficiency and risk affect market share in European banking industry. Our analysis is motivated by the well-known efficiency hypothesis and structure-conduct-performance theory. We hypothesize that improved efficiency and enhanced riskiness of a bank should be related to an increase in its market share. Therefore, in contrast to other studies, we include risk as a determinant of market share. In the study we use annual data for 36 European countries' banks for the time span from 2007 to 2015. The results reveal that risk and efficiency are positively associated with market share of assets, loans and deposits. Additionally, we find that banks in transition countries were less successful in transposing their cost efficiency advantages into market share gains than banks in European developed countries. The empirical model is estimated by using the GMM method in order to account for dynamic nature of investigated components and to mitigate the endogeneity problem.
\end{abstract}

Key words: bank efficiency, risk, market share

JEL classification: G21, L22

\footnotetext{
* Received: 10-06-2019; accepted: 19-12-2019

1 Senior Lecturer, University for Business and Technology, Faculty of Business Management and Economics. Lagjja Kalabria, 10000 Prishtina, Kosovo. Scientific affiliation: microeconomics of banking, risk management, financial economics. Phone: +383 38541 400. Fax: +383 38542 138. E-mail: bashkim.nurboja@ubt-uni.net (corresponding author).

2 Full Professor, University of Ljubljana, Faculty of Economics, Kardeljeva ploščad 17, 1000 Ljubljana, Slovenia. Scientific affiliation: banking management, risk management, financial institution markets. Phone: +38615892400, Fax: +38615892698. E-mail: marko.kosak@ ef.uni-lj.si. Personal website: http://www.ef.uni-lj.si/osebe/Marko-Kosak.
} 


\section{Introduction ${ }^{3}$}

Competition for market share has traditionally been considered a source of excessive risk taking in the banking industry (Matutes and Vives, 2000). An increase in market share is usually considered as a strategy that afterwards allows firms to earn higher profits (Buzzell, Gale, and Sultan, 1975). For regulators and academics it is important to determine how firms increase market share: is it through efficiency or risk taking? These views are associated with the efficiency hypothesis (EH) and Structure-Conduct-Performance (SCP); both these views have policy implications if a regulator tries to intervene; the first suggests that policies against concentration might affect efficiency and as a result welfare; the second suggests that concentration may induce collusion, and as result, welfare loss. Thus, the weight of the market structure of banking systems is very relevant because of the firms' access to funds and their investment (González, 2009). Moreover, elevation of the market share of large banks tends to make smaller banks instable (Kim, Park, and Song, 2016).

In this study we ask how market share of total assets, loans and deposits in the banking industry increases, is it with higher risk taking and/or with higher efficiency. Market share measures the share that a bank holds in the market where it operates. Given that the banking industry is regulated and there are barriers to entry, demand is not horizontal, implying that banks may have some market power. Hence, banks are inclined to increase market share because that will enable them to earn abnormal profits. The game race between banks, as to which one can accumulate capital or increase market share faster, happens because banks are constrained by their capital (Allen and Gale, 2004). Thus, the market share strategy is an important factor for banks, because managers might think that the effect of their activities will have an impact not only on immediate profit but also on their future position in the market. Although, the future position of a bank depends on risk taking and/or cost efficiency and on the behavior of other banks. Managers can pursue the target of increasing market share, by issuing loans without proper screening, increase interest rates on deposits, and not monitoring the performance of loan takers, knowing that screening and monitoring are important for understanding the strategies (Francis, Hasan, Küllü, and Zhou, 2018). All these actions will eventually increase market share in the banking industry, but the risk for default will be much higher. On the other hand, banks can increase their market share by being more efficient, and as a result have an advantage on pricing; or they can differentiate themselves by providing a better quality service.

This study examines how banks in European countries increase their market share and how this is related to efficiency and risk taking. We extended previous research

$\overline{3}$ This article is part of $\mathrm{PhD}$ dissertation with title "Efficiency and Market Structure of Banking Industry in Southeast Europe", it was modified for publication. 
on market structure by including the risk variable that was derived from a utility maximization model suggested by Hughes, Lang, Mester and Moon(1996). The risk variable is defined as the standard deviation of expected returns, a model which allows banking managers to choose the input factors given their expected return and standard deviation of expected return (Hughes et al., 2000). This allows us to check if the risk-taking is correlated with market share. Moreover, we check if there is any difference between the banks in transition countries and the European developed countries regarding the market share. Furthermore, we include cost efficiency score, which we derive through the Stochastic Frontier Approach (SFA), as an independent variable to check if the market share is correlated with efficiency. In order to examine effects of efficiency and risk better, we control for mergers and acquisition within the country and other environment variables.

This paper contributes to the literature by trying to answer the question, how cost efficiency and risk taking affect the market share. We extended the previous work of González (2009) and Efthyvoulou and Yildirim (2014) by including the risk variable and cost efficiency scores. We found that risk in a previous period is correlated with market share in the current period. Moreover, we found that efficiency is correlated with market share of assets, loans and deposits. We have estimated the model using the GMM model in order to account for dynamics and to avoid the endogeneity problem. We have used annual data for 36 European countries' banks for the years 2007-2015, because it covers the post crisis period. During this period many inefficient banks have been trying to improve cost efficiency (Nurboja and Košak, 2017) and some banks engaged in mergers and acquisitions.

The rest of this paper is organized as follows: Section 2 contains a literature review on banking market structure. Section 3 covers the methodology and data. The results are interpreted in Section 4. The last Section includes the conclusions.

\section{Literature review}

\subsection{Risk-taking in the context of market share}

The agency costs theory explains that when firms are financed by debt, managers acting in the shareholders' interests have an incentiveto take higher risk, because the debt holders bear the risk if things go wrong while the shareholders benefit if things succeed(Berger and Bonaccorsi di Patti, 2006; Jensen and Meckling, 1976). Thus, banking managers are inclined to take higher risk and expect that to be translated into higher market share and ultimately to lead to higher profit. Hence, their compensation schemes are linked to the performance.

The risk-expected return trade-off is determined by the investment strategy that banking managers choose (Hughes and Mester, 2013). The decision taken by 
banking managers depends on their utility function, which is a function of expected return and its standard deviation. Banks exogenously may set the level of risk they take on their investments and the intensity of monitoring and screening (Freixas and Rochet, 2008). If these decisions affect the market share, then we may conclude that the banks are not risk neutral, hence the banks through higher market share may tend to rise the profitability. Zamore,Djan, Alon, and Hobdari(2018) found six streams of risk measurement which were used in different models. In our case, we will use as risk the standard deviation of expected return as suggested by (DeYoung, Hughes, and Moon, 2001; Hughes et al., 2000; Hughes and Mester, 2013).

Some authors, for example Pawlowska (2016), treat market share as explanatory variable in relation to risk, whereas the relation should be vice versa. The decisions of banking managers that are related to risk could affect market share, for example to increase the interest rate for deposits, is a risky decision that may cause an increase on market share of deposits, due to higher supply of deposits for that particular bank. Or, if banking managers decide not to utilize the screening instruments of potential borrowers, they may increase the market share of loans. Indeed, there may be a lag before the risk taking affects the market share, because any decision that the bank manager takes needs time to have an effect. In this context, we included the risk on the right-hand side as a predetermined variable and hypothesize that the lag risk affects market share in current period.

\subsection{Efficiency hypothesis in market share context}

Efficiency hypothesis implies that firms increase their market share because they are efficient in comparison to their peers. Therefore examination of the market structure in banking is important because optimal allocation of resources may be altered. Researchers and policymaker have put great effort into determining what policies should be implemented in the banking industries regarding the concentration, given their importance. Many authors have tried to measure market structure by examining the variation of profitability in relation to concentration or market share. Thus, the market structure variables were considered as exogenous variables. For example Mirzaei, Moore, and Liu (2013) used market share to explain variation of profitability for advanced and transition economies. Some studies where market share was treated as endogenous are Berger and Hannan (1998) and Berger (1995); they claimed that market share can be explained only by scale efficiency in the US banking market. For Europe, Goldberg and Rai (1996) claimed that there is no relation between efficiency and market structure. Many other studies have tried to investigate this relationship, however, some of them support the efficiency hypothesis but some find no correlation of efficiency with market share. 
Banks, like all other firms, compete for market share, on the assumption that will result in market power ${ }^{4}$, either by taking higher risk and waiting for reward or by being more efficient than their peers and as result gain market share. Concentration in the industry is correlated with the efficiency, affirming that the most efficient banks obtain higher market shares, because, banks that operate more efficiently than their peers are able to lower their prices or provide better service and as result gain market share (Boulding and Staelin, 1990; Demsetz, 1973). In contrast, Berger and Hannan (1998) tested the "quiet life hypothesis" for banking industry in the US and found that banks in more concentrated markets exhibit lower cost efficiency. This raises the question: how do banks increase their market share? Is it by investing in the high risk projects ${ }^{6}$ ? And/Or, do the managers work very efficiently by offering more competitive pricing of better products, which they can afford due to greater cost of efficiency, and can therefore increase their market share? We can assume that banks compete for market share, because the bank that manages to get the largest share might be able to exploit its market power to increase profitability.

In contrast to aforementioned studies, we tried to examine what affects market share of assets, loans and deposits. Since some studies treated efficiency as endogenous, we have decided to include lagged efficiency scores, because the efficiency in the current period might affect market share in the future period. Thus, we hypothesize that efficiency is correlated with the market shares. In addition, given that, in our sample, we have banks from transition countries and European developed countries, where the institutional settings may differ, we investigate how efficiency affects the market share of banks in these groups of countries. Moreover, knowing that banks are mostly financed by debt, according to the agency theory we would expect that bank managers are inclined to take risk in the interests of their shareholders and at the expense of debt holder. If the risk consequences do not occur, the bank managers claim the reward. Consequently, we expect that risk taking is related with market share.

In sum, many studies have tried to measure market structure, but, to our knowledge, there are no studies that have included efficiency and risk in one model to determine market share. Moreover, our study covers a large set of European countries, which will offer new insight regarding the market structure.

\footnotetext{
${ }^{4}$ Industrial Organization literature suggests that the higher the market power firms possess, the more they will be able to increase markup.

5 This hypothesis postulates that the higher the market power, the lower the effort of managers to maximize operating efficiency.

${ }^{6}$ Risky project not only applies to new investment, but to the operation process as well. For example, not hiring enough loan officers to monitor borrowers can be regarded as a risky investment; hence, if loans do not default, the bank will earn more, or if more loan officers are employed, then they can better screen and monitor the firms.
} 


\section{Methodology}

In this model, equation (1), we will try to measure how market share is affected by risk and efficiency. We use two models, fixed effect and GMM. The risk scores was generated by using model of Hughes et al. (2000) and Hughes et al. (1996) (for more details how risk is measured see Appendix 1). The risk is represented by the standard deviation of the expected return of the banks. The risk was included as an independent variable in order to measure whether risk-taking influences the market share. The cost efficiency scores will be measured using the stochastic frontier approach (Battes and Coelli, 1995). The empirical specification is:

$$
\begin{aligned}
& M S_{i t}=\alpha_{0}+\alpha_{1} M S_{i t-1}+\beta_{1} R i s k_{i t}+\beta_{2} R i s k_{i t-1}+\varphi_{1} E F_{i t}+\varphi_{2} E F_{i t-1}+ \\
& +\delta I D_{i t}+\vartheta M \& A_{i t}+\boldsymbol{\theta}_{\boldsymbol{i}} \boldsymbol{h}_{i t}+\varepsilon_{i t}
\end{aligned}
$$

MS (market share) represents a vector of market shares of a bank $i^{\text {th }}$ associated with Total Assets, Loans and Deposits at time $t$. In our case we transformed the market share variables into natural logarithms in order to improve normality of the variable. The risk, depending on which market share we measure, may have different effects. The higher risk may be ambivalent; hence the banking managers increase banking assets by taking a higher risk that may translate into a higher market share or if the risk-taking fails market share may contract. In the context of market share of deposits, we may expect ambivalent relation with risk; if the market could read the risk taken, the market share of deposit may contract due to market discipline. The risk lag was included because we may expect that the risk taken in the current period may influence the market share in next period.

The $E F$ and $E F$ lag stand for cost efficiency scores. The efficiency hypothesis claims that market share and efficiency are endogenous because efficiency in the current period may affect market share in the next period (González, 2009). Also, as "quitelife hypothesis" states that market share may affect the efficiency in negative way, or the efficiency may be affected positively by market share through the economy of scale. Therefore, we used system GMM and introduced a lag $E F$ to solve the problem of endogeneity. Several papers supported the efficiency hypothesis view that efficiency is associated with market share in the banking sector (Chortareas, Garza-Garcia, and Girardone, 2011; González, 2009). However, in the banking sector, which is a regulated industry, the banks with higher efficiencies may not be able to exploit its market power.

The $I D$ stands for income diversification. Banks that diversify their income more may have a lower market share on loans because they shift resources to other outputs. Thus, we expect that $I D$ will be negatively correlated with market share of loans. The ID may be ambivalent with market share of assets, because the resources that were allocated to other earning assets depend on marginal revenue of 
units allocated to other earning assets. In terms of market share of deposits, the ID may have ambivalent effect, because that may depend how depositors perceive the riskiness of invested assets that generate other income.

The merger and acquisition $(M \& A)$ were included in order to account for rapid market share gain, which is not captured from risk and efficiency. The $M \& A$ were identified only within the country; we have not accounted for cross-border $M \& A$, because we measure market share of the level of each country. We also have estimated the equation (1) without inclusion of M\&A where we assumed that some managerial decisions to undertake M\&A are risky.

The $h$ is a vector of variables that we have included to control for heterogeneity. We estimated equation (1) using three specifications. In each specification we used different market share as dependent variable. We have included the dummy for banking systems of transition countries (1, otherwise zero), where the benchmark is banks in the European developed countries. We expect that banks in transition countries gain market share more slowly than banks in the European developed countries as result of efficiency because of financial reforms and quality of institutions (Delis, 2012). Thus, we have included an interaction between group of banks from transition countries and efficiency. In order to control for heterogeneity between countries we controlled for size of economy by including the GDP (natural logarithm of GDP) and for financial development by including banks' assets $^{7}$ to GDP (Beck, Demirgüç-kunt, and Levine, 2000). The $\varepsilon$ is a disturbance term normally distributed $\varepsilon \sim N\left(0, \sigma^{2}\right)$. In addition to the fixed effect model, we use system GMM model in order to avoid endogeneity problem and account for dynamics (Arellano and Bond, 1991; Blundell and Bond, 1998).The instruments that the GMM system uses for endogeneity are verifiable by means of the Sargan test, where the null hypothesis states that overidentifying restrictions are valid cannot be rejected (see Table 2 and Table 3 ).

\section{Empirical data and analysis}

In this study we use annual banking data for 576 commercial banks from 36 European countries for the period 2007-2015. The data were collected through Bankscope; data were converted to the currencies to Euros and adjusted for inflation as the base year was taken 2007 through the Bankscope platform. Country level data were obtained from World Bank Data. The banks that were not active have been omitted. The descriptive statistics are presented in Table 1, we have divided the sample of banking systems into transition countries ${ }^{8}$ and European developed countries.

\footnotetext{
7 The sum of all banks assets in year tfor a particular country divided by its GDP for the same year.

8 Transtion countires are considered all the countries in the sample that undergone through a regime change. For details, please see appendix no. 5.
} 
Table 1: Descriptive statistics of variables for transition and European developed countries

\begin{tabular}{|c|c|c|c|c|c|c|c|c|c|c|}
\hline & \multicolumn{4}{|c|}{ Transition Countries } & \multicolumn{4}{|c|}{ European developed countries } & \multicolumn{2}{|c|}{ All } \\
\hline & Mean & SD & Min & $\operatorname{Max}$ & Mean & SD & Min & $\operatorname{Max}$ & Mean & SD \\
\hline \multicolumn{11}{|l|}{ Dependent variables } \\
\hline Market share of assets & 0.080 & 0.092 & 0.002 & 0.522 & 0.059 & 0.138 & 0.003 & 0.487 & 0.070 & 0.125 \\
\hline Market share of deposits & 0.088 & 0.101 & 0.002 & 0.531 & 0.061 & 0.136 & 0.001 & 0.466 & 0.071 & 0.126 \\
\hline Market share of loans & 0.086 & 0.103 & 0.003 & 0.533 & 0.060 & 0.134 & 0.002 & 0.457 & 0.070 & 0.124 \\
\hline \multicolumn{11}{|l|}{ Independent Variables } \\
\hline Risk $^{\#}$ & 0.013 & 0.008 & 0.003 & 0.120 & 0.022 & 0.024 & 0.002 & 0.270 & 0.017 & 0.020 \\
\hline Efficiency $\$$ & 0.812 & 0.100 & 0.081 & 1.000 & 0.827 & 0.088 & 0.358 & 0.989 & 0.812 & 0.097 \\
\hline Income diversification & 0.431 & 0.318 & 0.280 & 0.983 & 0.482 & 0.252 & 0.02 & 0.986 & 0.438 & 0.306 \\
\hline GDP* & 231 & 291 & 7.2 & 1435 & 1470 & 917 & 121 & 3540 & 876 & 934 \\
\hline Asset to GDP & 0.381 & 0.277 & 0.037 & 1.677 & 2.236 & 1.152 & 0.351 & 5.355 & 1.363 & 1.259 \\
\hline HHI Assets & 2876 & 1361 & 876 & 9120 & 1810 & 935 & 872 & 8111 & 2371 & 1293 \\
\hline
\end{tabular}

Note: ${ }^{\#}$ Risk is generated according to Hughes et al.,(2000), check appendix 1; ${ }^{\text {Efficiency is cost }}$ efficiency that was generated through the stochastic frontier approach(Battese \& Coelli, 1995), check appendix 2 ; ${ }^{*} \mathrm{GDP}$ is in billions of $€$.

Source: Bankscope, World Bank and authors' estimations

The market shares of assets, market share of deposits and market share of loans were estimated (MS = Asset of the Bank $k_{i t} / \sum_{i=1}^{n}$ Assets of the Banks $s_{t}$ where $n$ is the number of banks within the national markets $t=2007, \ldots, 2015)$. The risk variable measures standard deviation of expected return, which was derived according to the Hughes et al., (2000) and Koetter (2008). Inclusion of risk will try to capture the risky decisions that managers make to maximize their utility function (check appendix 1). In terms of efficiency, we used stochastic frontier approach as suggested by Battes and Coelli (1995) to derive efficiency scores, then we include the efficiency score variable as independent variable (for details check appendix 2).

The income diversification was estimated according to Laeven and Levine (2007).

$$
\text { Income diversification }=1-\text { abs }\left(\frac{\text { interest income }- \text { other operating income }}{\text { Total operating income }}\right)
$$

This index can take values from zero to one, where zero means that the bank has a solely one stream of income. The higher the index, the greater the income diversifications.

As we can notice from Table 1 the market share on average is higher in transition countries than European developed countries, whereas, efficiency is higher in the European developed countries at the statistical significance. Thus, we argue that inclusion of interaction between efficiency and group of banking systems would show if there is a difference in speed of market share gains through the efficiency. 
There is a difference in financial development between these groups of countries; the asset to GDP ratio shows that European developed countries have much higher financial development than transition countries. In Appendix 3 we have presented the correlation matrix table of variables. The correlation between market share variables of assets, loans and deposits is above 0.9 .

In order to control for the M\&A effect we had to identify mergers and acquisitions within national markets. Therefore we introduced M\&A dummy variable that takes value of 1 in case a domestic M\&A occurred and value of 0 otherwise. In our sample we have identified 17 M\&A during the period 2007-2015 (see Appendix 4 for country by country). In our identification process of M\&A, we have arbitrarily taken a change 0.05 in market share of assets of a bank as the basis for filtering data. Only two banks appeared to have a change of market share of assets of more than 0.05 . Then we have investigated the websites of those banks and press releases for those particular years, in order to confirm that M\&A occurred. We decreased the change in market share of assets to 0.04 as the criterion for filtering. The number of banks that appeared was 22. From 22 banks we found out that only 17 had undertaken M\&A. After we decreased the change in market share of assets to 0.03 and filtered the database, 37 banks appeared, but none of the additional banks had undertaken any M\&A activities. Thus, only for these 17 banks we have included a dummy variable from the year that M\&A took place.

The estimated empirical models are presented in Table 2 and Table 3. We noticed persistence in the dynamic parameters of the dependent variables, where the market share increase in the previous period affects the market share in the current period. Moreover, the results show that lagged risk is positively associated with the market share in three specifications. The parameter of current risk with the GMM model appeared not to be significant, except for market share of deposits in Table 2. These results confirm our hypothesis that the risk affects the market share.

We see that income diversification is one of the drivers that explains market share but not in the same way for all the dependent variables. Income diversification appeared negatively correlated with market share of loans and significant. In case of GDP and financial development (Assets to GDP) the relation is negative with market share and in most cases it is significant. This shows that, as economic and financial development increases, market share decreases. This results are in line with González (2009).

In Table 2 we show differences for the group of banking systems from transition countries compared with those from European developed countries in interaction with efficiency. The results reveal that banks in transition countries translate efficiency to market share slower than banks from European developed countries. 
The parameter estimated with the transition countries dummy (TC) turns out to be strictly significant and positive in all specifications, which indicates a persistent tendency towards greater market shares in banking industries of the transition countries included in the study.

Table 2: Estimated result with M\&A

\begin{tabular}{|c|c|c|c|c|c|c|}
\hline \multirow{2}{*}{ Dependent variable } & \multicolumn{3}{|c|}{ Fixed effect } & \multicolumn{3}{|c|}{ System GMM } \\
\hline & MS assets & MS loans & MS deposits & MS assets & MS loans & MS deposits \\
\hline MS Assets $_{t-1}$ & $\begin{array}{r}0.986 * * * \\
(0.004)\end{array}$ & & & $\begin{array}{r}0.954 * * * \\
(0.050)\end{array}$ & & \\
\hline MS Loans ${ }_{t-1}$ & & $\begin{array}{r}0.985 * * * \\
(0.004)\end{array}$ & & & $\begin{array}{r}1.011 * * * \\
(0.075)\end{array}$ & \\
\hline MS Deposits ${ }_{t-1}$ & & & $\begin{array}{r}0.994 * * * \\
(0.007)\end{array}$ & & & $\begin{array}{r}1.056^{* * * *} \\
(0.037)\end{array}$ \\
\hline Risk & $\begin{array}{r}1.175 * * * \\
(0.313)\end{array}$ & $\begin{array}{r}0.881 * * \\
(0.345) \\
\end{array}$ & $\begin{array}{r}2.749 * * * \\
(0.546)\end{array}$ & $\begin{array}{r}0.663 \\
(0.452) \\
\end{array}$ & $\begin{array}{r}0.207 \\
(0.583) \\
\end{array}$ & $\begin{array}{c}1.714 * \\
(0.836) \\
\end{array}$ \\
\hline $\operatorname{Risk}_{t-1}$ & $\begin{array}{r}1.321 * * * \\
(0.308)\end{array}$ & $\begin{array}{c}0.881 * \\
(0.344) \\
\end{array}$ & $\begin{array}{r}2.168 * * * \\
(0.532) \\
\end{array}$ & $\begin{array}{r}1.442 * * * \\
(0.397)\end{array}$ & $\begin{array}{c}1.165^{*} \\
(0.469) \\
\end{array}$ & $\begin{array}{c}1.439 * \\
(0.720) \\
\end{array}$ \\
\hline Efficiency & $\begin{array}{r}0.229 * * \\
(0.112) \\
\end{array}$ & $\begin{array}{r}0.051 * * \\
(0.024) \\
\end{array}$ & $\begin{array}{r}0.121 \\
(0.177) \\
\end{array}$ & $\begin{array}{r}0.192 * * \\
(0.080) \\
\end{array}$ & $\begin{array}{r}0.096 \\
(0.220) \\
\end{array}$ & $\begin{array}{l}0.045^{*} \\
(0.028) \\
\end{array}$ \\
\hline Efficiency $_{t-1}$ & $\begin{array}{r}0.230 * * \\
(0.088) \\
\end{array}$ & $\begin{array}{c}0.153 * \\
(0.088) \\
\end{array}$ & $\begin{array}{r}0.164 * * * \\
(0.053) \\
\end{array}$ & $\begin{array}{r}0.183 * * * \\
(0.024)\end{array}$ & $\begin{array}{r}0.382 * * \\
(0.157) \\
\end{array}$ & $\begin{array}{r}0.115 * * * \\
(0.038)\end{array}$ \\
\hline ID & $\begin{array}{l}0.067 * \\
(0.030) \\
\end{array}$ & $\begin{array}{r}-0.002 * * * \\
(0.000)\end{array}$ & $\begin{array}{r}0.004 \\
(0.053) \\
\end{array}$ & $\begin{array}{r}0.356^{* * *} \\
(0.055)\end{array}$ & $\begin{array}{r}-0.112 * * \\
(0.063) \\
\end{array}$ & $\begin{array}{c}0.341^{* *} \\
(0.106) \\
\end{array}$ \\
\hline GDP & $\begin{array}{c}-0.001 * \\
(0.000) \\
\end{array}$ & $\begin{array}{r}-0.020 * * \\
(0.010) \\
\end{array}$ & $\begin{array}{r}-0.001 \\
(0.001) \\
\end{array}$ & $\begin{array}{r}-0.011 * * \\
(0.005) \\
\end{array}$ & $\begin{array}{r}-0.000 \\
(0.000) \\
\end{array}$ & $\begin{array}{c}-0.001 * \\
(0.000) \\
\end{array}$ \\
\hline Asset to GDP & $\begin{array}{c}-0.024 * \\
(0.010)\end{array}$ & $\begin{array}{r}-0.014^{* *} \\
(0.004) \\
\end{array}$ & $\begin{array}{r}0.010 \\
(0.018)\end{array}$ & $\begin{array}{r}-0.134 * * * \\
(0.031)\end{array}$ & $\begin{array}{c}-0.106^{*} \\
(0.043)\end{array}$ & $\begin{array}{r}-0.031 \\
(0.058)\end{array}$ \\
\hline $\mathrm{TC}^{\#}$ & $\begin{array}{l}0.056^{*} \\
(0.029)\end{array}$ & $\begin{array}{r}0.109 * * * \\
(0.018)\end{array}$ & $\begin{array}{r}0.285 * * * \\
(0.094)\end{array}$ & $\begin{array}{r}0.099 * * * \\
(0.037)\end{array}$ & $\begin{array}{r}0.667 * * \\
(0.305)\end{array}$ & $\begin{array}{r}1.470 * * \\
(0.612)\end{array}$ \\
\hline Transition*efficiency & $\begin{array}{l}-0.101 * \\
(0.068) \\
\end{array}$ & $\begin{array}{r}-0.098^{* * *} * \\
(0.028)\end{array}$ & $\begin{array}{c}-0.308^{*} \\
(0.191) \\
\end{array}$ & $\begin{array}{r}-0.294 * * * \\
(0.042) \\
\end{array}$ & $\begin{array}{r}-0.319 * * \\
(0.136) \\
\end{array}$ & $\begin{array}{c}-0.377^{*} \\
(0.229) \\
\end{array}$ \\
\hline$M \& A^{\&}$ & $\begin{array}{c}0.092 * \\
(0.042) \\
\end{array}$ & $\begin{array}{c}0.113^{*} \\
(0.044) \\
\end{array}$ & $\begin{array}{r}0.098 \\
(0.075) \\
\end{array}$ & $\begin{array}{r}0.750 * * * \\
(0.107)\end{array}$ & $\begin{array}{r}0.508 * * * \\
(0.135)\end{array}$ & $\begin{array}{r}0.691 * * * \\
(0.208)\end{array}$ \\
\hline Constant & $\begin{array}{r}-3.675 * * * \\
(0.267)\end{array}$ & $\begin{array}{r}-4.010^{* * *} \\
(0.274)\end{array}$ & $\begin{array}{r}-3.884 * * * \\
(0.380)\end{array}$ & $\begin{array}{r}0.387 \\
(0.395)\end{array}$ & $\begin{array}{l}0.706^{*} \\
(0.303)\end{array}$ & $\begin{array}{c}1.401 * * \\
(0.491)\end{array}$ \\
\hline Country fixed effects & Yes & Yes & Yes & & & \\
\hline$R^{2}$ & 0.36 & 0.25 & 0.30 & & & \\
\hline$A R 1$ (p-value) & & & & $(0.011)$ & $(0.031)$ & $(0.039)$ \\
\hline$A R 2$ (p-value) & & & & $(0.334)$ & $(0.343)$ & $(0.352)$ \\
\hline $\begin{array}{l}\text { Sargan-Hansen } \\
\text { (p-value) }\end{array}$ & & & & $(0.332)$ & $(0.423)$ & $(0.589)$ \\
\hline
\end{tabular}

Note: ${ }^{\#}$ Transition countries; ${ }^{\&}$ Mergers and Acquisitions, a list of the countries in the sample is provided in Appendix4; Standard errors are given in parentheses and $* * *$ denotes statistical significance at the $1 \%$ level, $* *$ at the $5 \%$ level and $*$ at the $10 \%$ level.

Source: Authors 
Bashkim Nurboja, Marko Košak • Cost efficiency and risk as determinants of market...

The banks that have undertaken merger and acquisitions, when compared with the banks that have not undertaken any mergers and acquisitions during this period haveon average higher market share in all specifications. This shows that big banks try tofurther increase the market sharethrough the M\&A, which leads to higher market concentration in the banking industry.

Table 3: Estimated results without M\&A

\begin{tabular}{|c|c|c|c|c|c|c|}
\hline \multirow{2}{*}{ Dependent Variable } & \multicolumn{3}{|c|}{ Fixed effect } & \multicolumn{3}{|c|}{ System GMM } \\
\hline & MS assets & MS loans & MS deposits & MS assets & MS loans & MS deposits \\
\hline MS Assets $_{t-1}$ & $\begin{array}{r}0.988 * * * \\
(0.004)\end{array}$ & & & $\begin{array}{r}0.958 * * * \\
(0.019)\end{array}$ & & \\
\hline MS Loans $_{t-1}$ & & $\begin{array}{r}0.987 * * * \\
(0.004)\end{array}$ & & & $\begin{array}{r}0.943 * * * \\
(0.073)\end{array}$ & \\
\hline MS Deposits $_{t-1}$ & & & $\begin{array}{r}0.997 * * * \\
(0.007)\end{array}$ & & & $\begin{array}{r}1.235^{* * * *} \\
(0.052)\end{array}$ \\
\hline Risk & $\begin{array}{r}1.150 * * * \\
(0.313)\end{array}$ & $\begin{array}{c}0.859 * \\
(0.346)\end{array}$ & $\begin{array}{r}2.733 * * * \\
(0.545)\end{array}$ & $\begin{array}{r}0.757 \\
(0.448)\end{array}$ & $\begin{array}{r}0.477 \\
(0.554)\end{array}$ & $\begin{array}{r}0.590 \\
(0.953)\end{array}$ \\
\hline Risk $_{t-1}$ & $\begin{array}{r}1.324 * * * \\
(0.308)\end{array}$ & $\begin{array}{c}0.907 * * \\
(0.346)\end{array}$ & $\begin{array}{r}2.180 * * * \\
(0.532)\end{array}$ & $\begin{array}{r}1.464 * * * \\
(0.386)\end{array}$ & $\begin{array}{c}1.049 * \\
(0.457)\end{array}$ & $\begin{array}{c}2.126 * * \\
(0.792)\end{array}$ \\
\hline Efficiency & $\begin{array}{c}0.266 * * \\
(0.098)\end{array}$ & $\begin{array}{c}0.116^{* *} \\
(0.054) \\
\end{array}$ & $\begin{array}{c}0.278^{*} \\
(0.150) \\
\end{array}$ & $\begin{array}{c}0.335^{*} \\
(0.140) \\
\end{array}$ & $\begin{array}{c}0.123^{*} \\
(0.066) \\
\end{array}$ & $\begin{array}{c}0.099 * \\
(0.058) \\
\end{array}$ \\
\hline Efficiency $_{t-1}$ & $\begin{array}{c}0.237 * * \\
(0.089)\end{array}$ & $\begin{array}{c}0.150 * \\
(0.083)\end{array}$ & $\begin{array}{l}0.182 * \\
(0.112)\end{array}$ & $\begin{array}{r}0.105 * * * \\
(0.026)\end{array}$ & $\begin{array}{c}0.443 * * \\
(0.152)\end{array}$ & $\begin{array}{r}0.163 * * * \\
(0.036)\end{array}$ \\
\hline ID & $\begin{array}{c}0.072 * * \\
(0.031)\end{array}$ & $\begin{array}{c}-0.004 * \\
(0.002)\end{array}$ & $\begin{array}{l}0.020 * \\
(0.011)\end{array}$ & $\begin{array}{r}0.240 * * * \\
(0.059)\end{array}$ & $\begin{array}{r}-0.095 * * \\
(0.041)\end{array}$ & $\begin{array}{c}0.143 * \\
(0.082)\end{array}$ \\
\hline GDP & $\begin{array}{r}-0.001 * * \\
(0.000)\end{array}$ & $\begin{array}{c}-0.000 \\
(0.000)\end{array}$ & $\begin{array}{r}-0.003 * * * \\
(0.000)\end{array}$ & $\begin{array}{r}-0.000 * * * \\
(0.000)\end{array}$ & $\begin{array}{r}-0.000 \\
(0.000)\end{array}$ & $\begin{array}{r}-0.000 \\
(0.000)\end{array}$ \\
\hline Asset to GDP & $\begin{array}{c}-0.017^{*} \\
(0.008)\end{array}$ & $\begin{array}{r}-0.008 \\
(0.008)\end{array}$ & $\begin{array}{r}0.009 \\
(0.014)\end{array}$ & $\begin{array}{r}-0.159 * * * \\
(0.027)\end{array}$ & $\begin{array}{c}-0.113 * \\
(0.044)\end{array}$ & $\begin{array}{r}-0.051 \\
(0.062)\end{array}$ \\
\hline $\mathrm{TC}^{\#}$ & $\begin{array}{r}0.237 * * * \\
(0.008)\end{array}$ & $\begin{array}{r}0.117 * * * \\
(0.006)\end{array}$ & $\begin{array}{r}0.165 * * * \\
(0.020)\end{array}$ & $\begin{array}{r}1.659 * * * \\
(0.374)\end{array}$ & $\begin{array}{r}0.328 * * \\
(0.162)\end{array}$ & $\begin{array}{r}3.253 * * \\
(1.021)\end{array}$ \\
\hline TC*efficiency & $\begin{array}{r}-0.035 * * * \\
(0.011)\end{array}$ & $\begin{array}{r}-0.022 * * \\
(0.010)\end{array}$ & $\begin{array}{r}-0.005 * * \\
(0.002)\end{array}$ & $\begin{array}{r}-0.274 * * \\
(0.138)\end{array}$ & $\begin{array}{l}-0.322 * \\
(0.185)\end{array}$ & $\begin{array}{r}-0.699 \\
(0.544)\end{array}$ \\
\hline HHI of assets & $\begin{array}{c}0.018 * \\
(0.010)\end{array}$ & $\begin{array}{c}0.008^{* *} \\
(0.004)\end{array}$ & $\begin{array}{l}0.007 * \\
(0.004)\end{array}$ & $\begin{array}{c}0.178^{*} \\
(0.099)\end{array}$ & $\begin{array}{c}0.076^{*} \\
(0.039)\end{array}$ & $\begin{array}{c}0.097 * * \\
(0.043)\end{array}$ \\
\hline Constant & $\begin{array}{r}-0.038 \\
(0.081)\end{array}$ & $\begin{array}{r}-0.018 \\
(0.087)\end{array}$ & $\begin{array}{r}0.021 \\
(0.143) \\
\end{array}$ & $\begin{array}{r}1.094 * * * \\
(0.208)\end{array}$ & $\begin{array}{r}0.216 \\
(0.323)\end{array}$ & $\begin{array}{r}2.373 * * * \\
(0.627)\end{array}$ \\
\hline Country fixed effects & Yes & Yes & Yes & & & \\
\hline$R^{2}$ & 0.32 & 0.31 & 0.34 & & & \\
\hline$A R 1$ (p-value) & & & & $(0.021)$ & $(0.031)$ & $(0.038)$ \\
\hline$A R 2$ (p-value) & & & & $(0.389)$ & $(0.401)$ & $(0.354)$ \\
\hline Sargan-Hansen (p-value) & & & & $(0.378)$ & $(0.398)$ & $(0.534)$ \\
\hline
\end{tabular}

Note: ${ }^{\#}$ Transition countries; a List of the countries in the sample is provided in Appendix 5; Standard errors are given in parentheses and $* * *$ denotes statistical significance at the $1 \%$ level, ** at the $5 \%$ level and $*$ at the $10 \%$ level.

Source: Authors 
In Table 3 we have estimated the equation (1) without M\&A and the results have appeared quite consistent with the results in Table 2. We also have included HHI to account for competition, but still the results show that banks from transition countries cannot translate the efficiency into the market share at the same pace as banks from European developed countries.

In the fixed effect model we have included country fixed effect, in order to avoid the country idiosyncratic characteristics. The hypothesis that the error term is not correlated cannot be rejected, which is shown by the Sargan-Hansen test for all three specifications. This implies that lags of efficiency used as instrument produce efficient estimators (Roodman, 2009). The AR (1) first order serial correlation is significant and AR (2) second order serial correlations is not significant. Thus, we continued with one lag as a dependent variable.

\section{Results and discussion}

In this study we analyze market share determinants in European banking industry and more specifically how cost efficiency and risk are related to changes in market shares. The results show that risk taken by banks in period t-1 is on average related to the contemporary market share of banks and in all model specifications this relationship was positive and significant. This finding may imply that higher risk taking by banks actually leads to increased market shares, which capacitates banks to enhance their profitability. However, as financial theory suggests the risk function is not expected to be linear, therefore the strategy of higher risk taking may not be advisable. In any case the risk mitigation techniques such as screening and monitoring should be in place and used adequately.

On the other hand, bank cost efficiency, estimated by the stochastic frontier approach, appears to be positively related to market share in the current period as well as in the period $\mathrm{t}-1$, which indicates that the efficiency hypothesis holds for these data and on average more cost efficient banks tend to dominate the markets. Consequently, policy makers should take into account this effect while addressing the market structure in the banking industry and thus detected elevated concentration rates, due to prevalence of superiorly efficient banks, can be tolerated, if the bank customers and other stakeholders benefit from the raised efficiency levels.

As regards the income diversification, a dedicated index shows that income diversification is positively related to market share of assets and deposits, but negatively to market share of loans, implying that banks that try to diversify their income streams, do so, by shifting output from loans to other earning assets. This observation is in line with our expectation and with a study by Efthyvoulou and Yildirim (2014), where they hypothesize that income diversification may occur due 
to a shift of resources fromloan production to other earning assets. In contrast to market share of loans, where estimated coefficient was negative, we observed that income diversification positively influenced market share of deposits and assets. Thus, a bank may increase income diversification as long as opportunity costs from shifting resources from loans to other earning assets are lower than income generated from other earning assets.

Our comparison of banking markets in transition countries with those in developed European countries shows that banks in transition countries on average havegreatermarket share than banks in the rest of Europe. By including the interaction terms in our empirical model, we find that banks in transition countries do not gain market share through efficiency as quickly as other European banks do. This may be due to the higher concentration rates of the banking industry in transition countries, where prices tend to be more rigid (Heggestad and Mingo, 1976). This particular finding indicates transition countries' banking sectors being characterized by distinctively more concentrated market structures, which very likely reflects differences in competitiveness and institutional settings between transition countries and economically more developed countries. One explanation for this result might be in the findings of Delis (2012), who discovered that banking competition did not improve at the same pace in countries with weaker institutions and lower levels of economic development, which was typically the case with the transitions countries in Europe. Additionally, our result could be also due to higher concentration of banking industries in transition countries (see HHI index in Table 1), which in turn might make prices more rigid (Berstein and Fuentes, 2005; Heggestad and Mingo, 1976).

We were also able to control for the M\&A effects in our study, which we consider as an especially valuable contribution of our study. As expected, the banks, that underwent M\&A in the observed period, on average controlled larger market shares than banks that have not been involved in any M\&As. This indicates that we can expect bigger banks tend to grow even bigger and consequently the market getting more concentrated.

\section{Conclusion}

In this study, we have examined what affects market share in the banking industry of 36 European countries for the period 2007-2015. Our main goal was to examine, how risk and efficiency affect market share of assets, loans and deposits. In addition to fixed effects, in order to avoid endogeneity between market share and efficiency, we used GMM. We found that an increase in risk in the previous period affects market share in the current period. In the fixed effects model the risk appeared significant, in contrast to the GMM model. This implies that banks can make risky 
decisions by not using the instruments of screening and monitoring and that may contribute to increase in the market share. However, how these decisions may influence costs of the bank in future, is beyond this research.

The efficiency hypothesis holds for our data, proving that efficiency is correlated with market share. We showed that the lag efficiency is also positively related with market share, implying that an increase in efficiency in the current period will affect market share in the next period. The banking systems of the transition countries are not able to exploit the efficiency increase, in terms of market share gain, as much as the banks in European developed countries. This may be due to higher concentration of the banking industry in transition countries, where the prices are more rigid. Moreover, we showed that income diversification is negatively related to market share of loans at the significant level. This means that banks that want to diversify income need to make a tradeoff between loan output and other earning assets. The banks that had undergone through the M\&A during the period of the sample, on average, have more market share than banks that have not made any M\&A. This concludes that bigger banks use M\&A as a way to increase market share and ultimately exploit the market power as a result.

Despite being carefully designed and executed, our study could be further improved and sophisticated by some methodological improvements and employment of a potentially richer data set. One aspect of the improvement relates to the risk measurement technique where risk is measured as a standard error of the expected return, reflecting overall aggregate risk of a particular bank in a specific period. A more advance approach should instead differentiate among different types of risk, like for example credit risk, market risk, foreign exchange risk etc., which could result in a more precise measurement how different types of risk affect market share of banks. We see the most serious obstacle for this kind of the extension in the limited availability of much more detailed data, while conceptually, the study could be designed in a similar way as our analysis. The second potential suggestion for further research is related to the approach typically used in the literature for market share measurement. Namely, market share variables used in most of the studies and in our analysis take into account only three the most common balance sheet categories, i.e. total assets, loans and deposits, while in reality market share and market power of an individual bank can also be expressed by some other parameters reflecting more transactional services provided by the banks for their customers (e.g. payment services). Again, also in this case limited availability of data represents an obstacle for this kind of extension of the analysis.

These results should be handled with care by policy makers. The results conclude that higher concentration may come through the risk taking, efficiency and M\&A decisions. However, the policies should not discourage the concentration as long as efficiency plays greater role in concentration and the risk is within the acceptable boundaries of the prudential regulation. Moreover, the policies that allow the 
efficient banks to take advantage of being efficient by gaining more market share might encourage banks to increase efficiency, especially the policies in transition countries.

\section{References}

Allen, F., \& Gale, D. (2004)"Competition and Financial Stability", Journal of Money, Credit and Bank, Vol 36, No 3, pp. 453-480, https://doi.org/10.1353/ mcb.2004.0038.

Arellano, M., \& Bond, S. (1991) "Some Tests of Specification for Panel Data: Monte Carlo Evidence and an Application to Employment Equations", The Review of Economic and Studies, Vol. 58, No. 2, pp. 277-297.

Battese, G. E., \& Coelli, T. J. (1995) "A Model for Technical Inefficicency Effects in a Stochastic Frontier Production Function for Panel Data", Empirical Economics, Vol 20, Nr. 2, pp. 325-332.

Beck, T., Demirgüç-kunt, A., \& Levine, R. (2000) "A New Database on Financial Development and Structure", Financial Sector Discussion Paper No. 2.

Berger, A. N. (1995) "The Profit-Strllcture Relationship in Banking Tests of Market-Power and Efficient-Structure Hypotheses", Journal of Money, Credit and Banking, Vol. 27, No. 2, pp. 404-431.

Berger, A. N., \& Bonaccorsi di Patti, E. (2006) "Capital structure and firm performance: A new approach to testing agency theory and an application to the banking industry", Journal of Banking \& Finance, Vol. 30, No. 4, pp. 10651102, https://doi.org/10.1016/j.jbankfin.2005.05.015.

Berger, A. N., \& Hannan, T. H. (1998) "The Efficiency Cost of Market Power in the Banking Industry: A Test of the "Quiet Life" and Related Hypotheses", The Review of Economics and Statistics, Vol. 80, No. 3, pp. 454-465, https://doi. org/10.1162/003465398557555.

Berstein, S.,\& Fuentes, R,. (2005) "Concentration and Price Rigidity: Evidence for the Deposit Market in Chile", Working Papers Central Bank of Chile 311, Central Bank of Chile.

Blundell, R., \& Bond, S. (1998) "Initial conditions and moment restrictions in dynamic panel data models", Journal of Econometrics, Vol. 87, No. 1, pp. 115143, https://doi.org/10.1016/S0304-4076(98)00009-8.

Boulding, W., \& Staelin, R. (1990) "Environment, Market Share, and Market Power", Management Science, Vol. 36, No. 10, pp. 1160-1177, https://doi. org/10.1287/mnsc.36.10.1160.

Buzzell, R. D., Gale, B. T., \& Sultan, R. G. M. (1975) "Market share: Key to profitability?", Harvard Business Review, Vol. 53, No. 1, pp. 97-106, https:// doi.org/10.1108/eb053944. 
Casu, B., \& Girardone, C. (2009) "Testing the relationship between competition and efficiency in banking: A panel data analysis", Economics Letters, Vol. 105, No. 1, pp. 134-137, https://doi.org/10.1016/j.econlet.2009.06.018.

Chortareas, G. E., Garza-Garcia, J. G., \& Girardone, C. (2011) "Banking Sector Performance in Latin America: Market Power versus Efficiency", Review of Development Economics, Vol. 15, No. 2, pp. 307-325, https://doi.org/10.1111/ j.1467-9361.2011.00610.x.

Deaton, A., \& Muellbauer, J. (1980) "An almost ideal demand system", The American Economic Review, Vol. 70, No. 3, pp. 312-326, http://doi.org/ 10.1016/0014-2921(94)90008-6.

Delis, M. D. (2012) "Bank competition, financial reform, and institutions: The importance of being developed", Journal of Development Economics, Vol. 97, No. 2, pp. 450-465, https://doi.org/10.1016/j.jdeveco.2011.05.012.

Demsetz, H. (1973) "Industry Structure , Market Rivalry, and Public Policy", The Journal of Law \& Economics, Vol. 16, No 1, pp. 1-9.

DeYoung, R. E., Hughes, J. P., \& Moon, C.-G. (2001) "Efficient risk-taking and regulatory covenant enforcement in a deregulated banking industry", Journal of Economics and Business, Vol. 53, No. 2, pp. 255-282, https://doi.org/10.1016/ S0148-6195(00)00044-8.

Dietsch, M., \& Lozano-Vivas, A. (2000) "How the environment determines banking efficiency: A comparison between French and Spanish industries",Journal of Banking \& Finance, Vol. 24, No. 6, pp. 985-1004, https://doi.org/10.1016/ S0378-4266(99)00115-6.

Efthyvoulou, G., \& Yildirim, C. (2014) "Market power in CEE banking sectors and the impact of the global financial crisis", Journal of Banking and Finance, Vol. 40, No. 1, pp. 11-27, https://doi.org/10.1016/j.jbankfin.2013.11.010.

Francis, B. B., Hasan, I., Küllü, A. M., \& Zhou, M. (2018) "Should banks diversify or focus? Know thyself: The role of abilities", Economic Systems, Vol. 42, No. 1, pp. 106-118, https://doi.org/10.1016/j.ecosys.2017.12.001.

Freixas, X., \& Rochet, J.-C. (2008) Microeconomics of Banking, Massachusetts: The MIT Press.

Fries, S., \& Taci, A. (2005) "Cost efficiency of banks in transition: Evidence from 289 banks in 15 post-communist countries", Journal of Banking and Finance, Vol. 29, No. 1, pp. 55-81, https://doi.org/10.1016/j.jbankfin.2004.06.016.

Goldberg, L. G., \& Rai, A. (1996) "The structure-performance relationship for European banking", Journal of Banking \& Finance, Vol. 20, No. 4, pp. 745-77, https://doi.org/10.1016/0378-4266(95)00021-6.

González, F. (2009) "Determinants of Bank-Market Structure : Efficiency and Political Economy Variables", Journal of Money, Credit and Banking, Vol. 41, No. 4, pp. 735-754. 
Heggestad, A. A., \& Mingo, J. J. (1976) "Prices, Nonprices, and Concentration In Commercial Banking", Journal of Money, Credit and Banking, Vol. 8, No. 1, pp. 107-117.

Hughes, J. P. and Moon, C., (1995) "Measuring bank efficiency when managers trade return for reduced risk", Department of Economics Rutgers University Working Paper, No. 1995-20.

Hughes, J. P., Lang, W., Mester, L. J., \& Moon, C.-G. (1996) "Efficient Banking under Interstate Branching", Journal of Money, Credit and Banking, Vol. 28, No. 4, pp. 1045-1071, https://doi.org/10.2307/2077940.

Hughes, J. P., Lang, W., Mester, L. J., \& Moon, C.-G. (2000) "Recovering Risky Technologies Using the Almost Ideal Demand System: An Application to U.S. Banking",Journal of Financial Services Research, Vol. 18, No. 1, pp. 5-27, https://doi.org/10.1023/A:1026554922476.

Hughes, J. P., \& Mester, L. J. (2013) "Who said large banks don't experience scale economies? Evidence from a risk-return-driven cost function",Journal of Financial Intermediation, Vol. 22, No. 4, pp. 559-585, https://doi.org/10.1016/j. jfi.2013.06.004.

Jensen, M. C., \& Meckling, W. H. (1976) "Theory of the Firm: Managerial Behavior, Agency Costs and Ownership Structure", Journal of Financial Economics, Vol. 3, No. 4, pp. pp. 305-360, https://doi.org/http://dx.doi.org/ 10.1016/0304-405X(76)90026-X.

Khorana, A., \& Servaes, H. (2012) "What drives market share in the mutual fund industry?", Review of Finance, Vol. 16, No. 1, pp. 81-113, https://doi. org/10.1093/rof/rfr027.

Kim, H., Park, K., \& Song, S. (2016) "Banking Market Size Structure and Financial Stability: Evidence from Eight Asian Countries", Emerging Markets Finance and Trade, Vol. 52, No. 4, pp. 975-990, https://doi.org/10.1080/1540496X. 2015.1025653.

Koetter, M. (2008) "The stability of bank efficiency rankings when risk preferences and objectives are different", The European Journal of Finance, Vol. 14, No. 2, pp. 115-135, https://doi.org/10.1080/13518470701380068.

Laeven, L., \& Levine, R. (2007) "Is there a diversification discount in financial conglomerates?”, Journal of Financial Economics, Vol. 85, No. 2, pp. 331-367, https://doi.org/10.1016/j.jfineco.2005.06.001.

Matutes, C., \& Vives, X. (2000) "Imperfect competition, risk taking, and regulation in banking", European Economic Review, Vol. 44, No. 1, pp. 1-34, https://doi. org/10.1016/S0014-2921(98)00057-9.

Mirzaei, A., Moore, T., \& Liu, G. (2013) "Does market structure matter on banks' profitability and stability? Emerging vs. advanced economies", Journal of Banking \& Finance, Vol. 37, No. 8, pp. 2920-2937, https://doi.org/10.1016/j. jbankfin.2013.04.031. 
Nurboja, B., \& Košak, M. (2017) "Banking efficiency in South East Europe: Evidence for financial crises and the gap between new EU members and candidate countries", Economic Systems, Vol. 41, No. 1, pp. 122-138, https:// doi.org/10.1016/j.ecosys.2016.05.006.

Nurboja, B. (2017) Efficiency and Market Structure of Banking Industry in Southeast Europe, PHD Thesis, University of Ljubljana.

Pawlowska, M. (2016) "Does the size and market structure of the banking sector have an effect on the financial stability of the European Union?", The Journal of Economic Asymmetries, Vol. 14, Part A, pp. 112-127, https://doi.org/10.1016/j. jeca.2016.07.009.

Roodman, D. (2009) "How to Do xtabond2: An Introduction to Difference and System GMM in Stata", The Stata Journal, Vol. 9, No. 1, pp. 86-136, https:// doi.org/The Stata Journal.

Staikouras, C., Mamatzakis, E., \& Koutsomanoli-Filippaki, A. (2008) "Cost efficiency of the banking industry in the South Eastern European region", Journal of International Financial Markets, Institutions and Money, Vol. 18, No. 5, pp. 483-497, https://doi.org/10.1016/j.intfin.2007.07.003.

Zamore, S., Ohene Djan, K., Alon, I., \& Hobdari, B. (2018) "Credit Risk Research: Review and Agenda", Emerging Markets Finance and Trade, Vol. 54, No. 4, pp. 811-835, https://doi.org/10.1080/1540496X.2018.1433658. 


\title{
Troškovna učinkovitost i rizik kao odrednice tržišnog udjela u bankarstvu: empirijski dokazi starih i novih država članica Europske unije i zemalja kandidata
}

\author{
Bashkim Nurboja ${ }^{1}$, Marko Košak ${ }^{2}$
}

\begin{abstract}
Sažetak
U ovom članku istražuje se kako troškovna učinkovitost i rizik utječu na tržišni udio u europskom bankarskom sektoru. Analiza je motivirana poznatom hipotezom učinkovitosti $i$ teorijom strukture-vođenja-uspješnosti. Hipoteza je da su poboljšana učinkovitost i pojačani rizik banke povezani s rastom tržišnog udjela banke. U odnosu na ostala istraživanja, u ovoj analizi uključen je rizik kao odrednica tržišnog udjela. U istraživanju se koriste godišnji podaci za 36 banaka iz europskih zemalja u razdoblju od 2007. do 2015. godine. Rezultati pokazuju da su rizik $i$ učinkovitost pozitivno povezani s tržišnim udjelom imovine, zajmova $i$ depozita. Nadalje, istraživanjem je utvrđeno da su banke u tranzicijskim zemljama bile manje uspješne u pretvaranju prednosti u pogledu troškovne učinkovitosti u povećanje tržišnih udjela od banaka u razvijenim europskim zemljama. Empirijski model je procijenjen korištenjem GMM metode kako bi se uzela u obzir dinamička priroda istraživanih komponenti te s ciljem zaobilaženja problema endogenosti.
\end{abstract}

Ključne riječi: bankovna učinkovitost, rizik, tržišni udio

JEL klasifikacija: G21, L22

1 Viši predavač, University for Busines and Technology, Faculty of Business Management and Economics.Lagjja Kalabria, 10000 Priština, Kosovo. Znanstveni interes: mikroekonomija bankarstva, upravljanje rizikom, financijska ekonomija. Tel.: +383 38541 400, Fax +383 38 542 138.E-mail: bashkim.nurboja@ubt-uni.net (osoba za kontakt).

2 Redoviti profesor, University of Ljubljana, Faculty of Economics Kardeljeva ploščad 17, 1000 Ljubljana, Slovenia. Znanstveni interes: upravljanje bankama, upravljanje rizicima, tržišta financijskih institucija. Tel.: +38615892400, Fax: +38615892698. E-mail: marko.kosak@ef. uni-lj.si. Osobna web stranica:http://www.ef.uni-lj.si/osebe/Marko-Kosak. 


\section{Apendices}

Appendix 1: Methodology for recovering the risk variable

This methodology was used according to Hughes et al. (1996) and Kotter (2008). Managers maximise utility by choosing optima profit and input demand. Let $\pi$ denote after tax profit. Technology stipulates the production plan of output quantities $y$, input quantities $x$, and capital $k$. The output prices are denoted by $p$. Managers form beliefs conditional on future states of the world $s$ as interaction with the plan production $(y, x, p, k)$ to determine profit $\pi=(y, x, p, k \mid s)$. Moreover, they form a subjective distribution of the prevailing states $s$. Therefore, this creates the conditional probability distribution of profit to be realised $f=(\pi \mid y, x, p, k, s)$. So, the approach to consider risk would be by defining utility as expected profit and its standard deviation $U(E(\pi), S(\pi))$. Since this risk modeling would not reveal the source of uncertainty which determines $S(\pi)$, Hughes et al. (1996) suggested that production plan $(y, x, p, k)$ can influence the utility.

Generalized Managerial Utility function, managers maximize utility $U(\pi, y, x, p, k)$ subject to transformation functionof the form $T(y, x, k)$ and the rank preferences of the profit. Let $m$ denote income from sources other than output $y$. In addition, let $t$ be tax rate on profit so that $p_{\pi}=1 /(1-t)$ depicts the price of after tax profit in terms of before tax profit. Then, nominal before tax accounting profit is given as:

$$
p_{\pi} \pi=p y+m-w x
$$

under the assumption of perfect competition in input and output markets. This ensures comparability with the case of the cost efficiency. Therefore, we write Utility maximisation problem:

$$
\begin{aligned}
& \max _{\pi, x} U(\pi, y, x, p, k) \\
& \text { s.t. } p_{\pi} \pi+w x=p y+m, \\
& \text { s.t. } T(y, x, z) \leq 0
\end{aligned}
$$

Solving this maximization problem for $\pi$ and $x_{i}$, we get the most preferred profit function and the most preferred input demand function:

$$
\begin{aligned}
& \pi^{*}=\pi^{*}(y, v, m, k) \\
& x_{i}^{*}=x_{i}^{*}(y, v, m, k)
\end{aligned}
$$

Where $v$ is a vector of the price environment of the bank $v=\left(w, p, p_{\pi}\right)$. The profit function $\pi^{*}$ is not necessary a profit maximising one from the traditional approach. 
Risk preferences are recovered from observed choices of production plans that banks has made. While the most preferred profit demand function is conditional on risk preferences we use it to estimate the benchmark frontier and to derive efficiency estimates.

\section{Empirical specification}

Since the equation (1) is not possible to estimate because of the unknown functional form and utility is not observable. In the context of banking firm, we estimate most preferred profit function and input demand function to gain insight into the preferences of bank managers. This is done by using the techniques from consumer theory that analysis the preferences for goods on basis of their expenditure and budget data. Hughes and Moon (1995) adopted Almost Ideal Demand System (AID) that was developed by Deaton and Muellbauer (1980) by using some Microeconomics techniques; first, the dual relation between the utility maximization problem (UMP) and the expenditure minimisation problem (EMP); second, the inverse relation of indirect utility and the expenditure function.

Duality allows restating equation (1) as minimization problem:

$$
\begin{aligned}
& \min _{\pi, x} w x+p_{\pi} \pi \\
& \text { s.t. } U^{0}-U(\pi, y, x, p, k)=0, \\
& \text { s.t. } T(y, x, k) \leq 0 .
\end{aligned}
$$

$U^{0}$ is the fixed level of utility. Solving the optimisation problem we get most preferred profit $\pi^{u}\left(y, v, k, U^{0}\right)$ and input demand function $x^{u}\left(y, v, z, U^{0}\right)$. According to Deaton and Muellbauer (1980) we can substitute the indirect utility function $V(y, v, m, k)$ for $U^{0}$ and then we have optimal demand functions as

$$
\begin{aligned}
& \pi^{u}(y, v, k, V(y, v, m, k))=\pi^{*}(y, v, m, k) \\
& x^{u}(y, v, k, V(y, v, m, k))=x^{*}(y, v, m, k)
\end{aligned}
$$

Where $x^{*}(\cdot)$ and $\pi^{*}(\cdot)$ are the demand functions given in equation (3) and (4) and $V(\cdot)$ depicts the indirect utility function. In the following we use the inverse relationship between indirect utility and the expenditure function, so by substitution we get:

$$
p y+m=E(y, v, k, V(y, v, m, k))
$$

Following, the AID in this case is not used to estimate demanded quantities directly. Instead, here we use Sheppard's Lemma to derive budget shares from the expenditure function. In Hughes et al. (1996) they adopted AID and define it as: 


$$
\ln E(\cdot)=\ln P+U * \beta_{0}\left(\prod_{i} \mathrm{y}_{\mathrm{i}}^{\beta_{\mathrm{i}}}\right)\left(\prod_{j} \mathrm{w}_{\mathrm{j}}^{\mathrm{v}_{\mathrm{j}}}\right) \mathrm{p}_{\pi}^{\mu} k
$$

Where $\ln P$ is the price index employed in the AID. Since the initial suggestionof Deaton and Muehlbauer (1980) many application in the consumer literature used the functional form of a translog for the price index. Therefore, we continue to use a translog functional form for the price index. Moreover, this functional form will allow a comparison with the cost minimising model. So, $\ln P$ is defined as

$$
\begin{aligned}
& \ln P=\alpha_{0}+\alpha_{p} \ln \tilde{p}+\sum_{i} \delta_{i} \ln y_{i}+\sum_{j} \omega_{j} \ln w_{j} \\
& +\eta_{\pi} \ln p_{\pi}+\rho \ln z+\frac{1}{2} \alpha_{p p}(\ln \tilde{p})^{2} \\
& +\frac{1}{2} \sum_{i} \sum_{j} \delta_{i j} \ln y_{i} \ln y_{j}+\frac{1}{2} \sum_{s} \sum_{t} \omega_{s t} \ln w_{s} \ln w_{t} \\
& +\frac{1}{2} \eta_{\pi \pi}\left(\ln p_{\pi}\right)^{2}+\frac{1}{2} \rho_{k k}(\ln k)^{2}+\sum_{j} \theta_{p j} \ln \tilde{p} \ln y_{j} \\
& +\sum_{s} \phi_{p s} \ln \tilde{p} \ln w_{s}+\psi_{p \pi} \ln \tilde{p} \ln p_{\pi}+\psi_{p z} \ln \tilde{p} \ln k \\
& +\sum_{j} \sum_{s} \gamma_{j s} \ln y_{j} \ln w_{s}+\sum_{j} \gamma_{j \pi} \ln y_{j} \ln p_{\pi} \\
& +\sum_{j}^{j} \gamma_{j z} \ln y_{j} \ln k+\sum_{s} \omega_{s \pi} \ln w_{s} \ln p_{\pi} \\
& +\sum_{s} \omega_{s z} \ln w_{s} \ln k+\eta_{\pi z} \ln p_{\pi} \ln k .
\end{aligned}
$$

Note that price of each output is not included. Instead we use an average price $\widetilde{p}$. The Hughes et al. (1996) showed that this help to conserve on degrees of freedom. Moreover, income earned per output is not readily available for transition countries.

In the following we derive share equation by applying Sheppard's Lemma to equation (9). We know that partial derivatives of the expenditure function with respect to goods' price are equal to respective budget shares. Knowing this we substitute the indirect utility function for the given utility $U^{0}$ into the derivatives $\frac{\partial \ln E(\cdot)}{\partial \ln w_{i}}$ and $\frac{\partial \ln E(\cdot)}{\partial \ln p_{\pi}}$. Substituting (8) into (9) and solving for utility, we get the indirect utility function as:

$$
V(\cdot)=\frac{\ln (p y+m)-\ln P}{\beta_{0}\left(\prod_{i} y_{i}^{\beta_{i}}\right)\left(\prod_{j} w_{j}^{v_{j}}\right)}
$$


The share equation for input demand and profit for a given level of utility are then depicted by:

$$
\begin{aligned}
& \frac{\partial \ln E}{\partial \ln w_{i}}=\frac{w_{i} x_{i}}{p y+m}=\frac{\partial \ln P}{\partial \ln w_{i}}+v_{i}[\ln (p y+m)-\ln P] \\
& =\omega_{i}+\sum_{s} \omega_{s i} \ln \omega_{s}+\phi_{p i} \ln \tilde{p}+\sum_{j} \gamma_{j i} \ln y_{i}+\omega_{\pi i} \ln p_{\pi} \\
& +\omega_{i z} \ln z+v_{i}\left[\ln (p y+m)-\ln P+\varepsilon_{w i}\right.
\end{aligned}
$$

and

$$
\begin{aligned}
& \frac{\partial \ln E}{\partial \ln p_{\pi}}=\frac{p_{\pi} \pi}{p y+m}=\frac{\partial \ln P}{\partial \ln p_{\pi}}+\mu[\ln (p y+m)-\ln P] \\
& =\eta_{\pi}+\eta_{\pi \pi} \ln p_{\pi}+\psi_{p \pi} \ln \tilde{p}+\sum_{j} \gamma_{j \pi} \ln y_{j}+\sum_{s} \omega_{s \pi} \ln w_{S} \\
& +\eta_{\pi z} \ln k+\mu[\ln (p y+m)-\ln P]+\varepsilon_{p_{\pi} .}
\end{aligned}
$$

According to the model in Deaton and Muehlbauer (1980) the parameters on consumed goods' prices are defined as:

$$
\omega_{s i}=\frac{1}{2}\left(\omega_{s i}^{*}+\omega_{i s}^{*}\right)=\omega_{i s} \text { and } \omega_{s \pi}=\frac{1}{2}\left(\omega_{s \pi}^{*}+\omega_{\pi s}^{*}\right)
$$

Moreover, several restrictions are imposed on the model due to symmetry and homogeneity:

$$
\delta_{i j}=\delta_{j i} \text { and } \omega_{s i}=\omega_{i s} \text { and } \omega_{s \pi}=\omega_{\pi s} \text { for all } i, j, s \text { and } \pi .
$$

The following restriction are:

$$
\begin{aligned}
& \sum_{j} v_{j}+\mu=0, \\
& \alpha_{p}+\sum_{j} \omega_{j}+\eta_{\pi}=1, \\
& \alpha_{p p}+\sum_{t} \phi_{j t}+\psi_{j \pi}=0 \\
& \phi_{p t}+\sum_{s} \omega_{s t}+\omega_{t \pi}=0
\end{aligned}
$$




$$
\begin{aligned}
& \theta_{p j}+\sum_{t} \gamma_{j t}+\gamma_{j \pi}=0, \\
& \eta_{\pi \pi}+\psi_{p \pi}+\sum_{s} \omega_{s \pi}=0, \\
& \psi_{p k}+\sum_{s} \omega_{s k}+\eta_{\pi k}=0, \\
& \frac{1}{2} \alpha_{p p}+\frac{1}{2} \sum_{s} \sum_{t} \omega_{s t}+\sum_{t} \phi_{p t}+\frac{1}{2} \eta_{\pi \pi}+\psi_{p \pi}+\sum_{s} \omega_{s \pi}=0 .
\end{aligned}
$$

To impose homogeneity we have to divide all prices by one of the goods' price, for simplicity, the Kotter (2006) suggests the price of physical capital. The last of restriction we need because the share derived from dual function must sum to one. The following restrictions are:

$$
\begin{aligned}
& \sum_{i} \omega_{i}+\eta_{\pi}=1, \\
& \sum_{i} \omega_{s i}+\omega_{s \pi}=0 \\
& \sum_{i} \phi_{p i}+\psi_{p \pi}=0 \\
& \sum_{i} \gamma_{j i}+\gamma_{j \pi}=0 \\
& \sum_{i} \omega_{\pi i}+\eta_{\pi \pi}=0 \\
& \sum_{i} \omega_{i k}+\eta_{\pi k}=0 \\
& \sum_{i} v_{j}+\mu=0
\end{aligned}
$$

To impose the adding up restrictions the share equation of demand for physical capital is dropped from system. Thus, we are left with system of three equations. After substituting the price index $\ln P$ from equation (10) into share equations (12) 
and (13) and collecting terms, the final system results. The collection of the term can be done with nonlinear seemingly unrelated regression equation (nlSURE). From here we follow Hughes et al. (1996) method and we use equation (13) to measure expected return and risk. Expected return on equity is the predicted profit divided by financial capital, ER $=\frac{E\left(p_{\pi} \pi\right)}{k}$. Whereas, Risk, is measured as a standard error of the expected return, Risk $=S\left(\frac{E\left(p_{\pi} \pi\right)}{k}\right)$.

Appendix 2: Recovering cost efficiency variable

The stochastic frontier approach (SFA) was used to recover cost efficiency scores, we have used Battes and Coelli (1995) model technique. The SFA approach allows for random errors, which diminishes the problem with measurement errors (Staikouras, Mamatzakis, \& Koutsomanoli-Filippaki, 2008). The distance from frontier will reflect the bank cost efficiency of all banks relative to the 'best practice' bank. We have included the controls for cross-country differences in the economic and financial environment, respectively, GDP and total banking assets to GDP. These differences may play a role in efficiency terms (Dietsch \& LozanoVivas, 2000).

In following we present a model:

$T C_{i t}=f\left(P_{i t}, Y_{i t} ; \boldsymbol{\beta}\right)+\varepsilon_{i t} ;$ where $\varepsilon_{i t}=v_{i t}+u_{i t} \quad i=1, \ldots, N \quad t=1, \ldots, T$

$T C_{i t}$ stands for bank total costs for bank $i$ at year $t, P$ represents vector of input prices, $Y$ represents outputs of banks, $\beta$ is a vector of parameters to be estimated and $\varepsilon_{i t}$ contains $v_{i t}$ which is assumed to be normally distributed around the frontier $v_{i} \sim N\left(0,+\sigma_{v}^{2}\right)$, which captures unobserved phenomena, and $u_{i t}$ is assumed as the truncated normal distribution $u_{i} \sim N\left(0,+\sigma_{u}^{2}\right)$, which captures inefficiency, and is independent of $v_{i}$.

In our empirical specification we used translog function, which was used by many authors, example Fries \& Taci (2005) and Nurboja \& Košak (2017).

$$
\begin{aligned}
& \ln T C_{i t}=\alpha_{0}+\sum_{j=1}^{3} \beta_{j t} \ln Y_{j t}+\sum_{i=1}^{2} \alpha_{i} \ln P_{i t}+\frac{1}{2} \sum_{i=1}^{2} \sum_{m=1}^{2} \alpha_{i m} \ln P_{i t} \ln P_{m t}+ \\
& +\frac{1}{2} \sum_{j=1}^{3} \sum_{k=1}^{3} \beta_{j k} \ln Y_{j t} \ln Y_{k t}+\sum_{i=1}^{3} \sum_{j=1}^{3} \delta_{i j} \ln P_{i t} \ln Y_{j t}+\varphi \ln \boldsymbol{X}_{i t}+V_{i t}+U_{i t}
\end{aligned}
$$

After running the estimation we have saved efficiency scores and we used it as variable in our models for market share. 
Appendix 3: Correlation matrix of variables

\begin{tabular}{|c|c|c|c|c|c|c|c|c|c|}
\hline & $\begin{array}{c}\text { MS } \\
\text { Assets }\end{array}$ & $\begin{array}{c}\text { MS } \\
\text { Deposits }\end{array}$ & $\begin{array}{c}\text { MS } \\
\text { Loans }\end{array}$ & Risk & Efficiency & $\begin{array}{c}\text { Income } \\
\text { Diversification }\end{array}$ & GDP & $\begin{array}{l}\text { Assets } \\
\text { to GDP }\end{array}$ & $\begin{array}{c}\text { HHI } \\
\text { Assets }\end{array}$ \\
\hline S Assets & 1.000 & & & & & & & & \\
\hline MS Deposits & $0.981 *$ & 1.000 & & & & & & & \\
\hline MS Loans & $0.984 *$ & $0.970^{*}$ & 1.000 & & & & & & \\
\hline Risk & $0.113 *$ & $0.097 *$ & $0.102 *$ & 1.000 & & & & & \\
\hline Efficiency & $0.048 *$ & $0.043 *$ & $0.056^{*}$ & -0.015 & 1.000 & & & & \\
\hline $\begin{array}{l}\text { Income } \\
\text { Diversification }\end{array}$ & $-0.012 *$ & $-0.014 *$ & $-0.051 *$ & $0.080^{*}$ & $-0.228 *$ & 1.000 & & & \\
\hline GDP & $-0.137 *$ & $-0.141 *$ & $-0.140 *$ & $0.227 *$ & $0.007 *$ & $0.178^{*}$ & 1.000 & & \\
\hline Assets to GDP & $-0.085^{*}$ & -0.090 & -0.082 & $0.264 *$ & $0.111^{*}$ & $0.153^{*}$ & 0.542 & 1.000 & \\
\hline HHI Assets & $0.280 *$ & $0.300 *$ & $0.291 *$ & 0.083 & $0.165^{*}$ & 0.010 & $-0.041 *$ & $0.151 *$ & 1.000 \\
\hline
\end{tabular}

Note: $*$ denotes statistical significance at the $5 \%$ level.

Appendix 4: No. of M\&A per country during the period 2007-2015

\begin{tabular}{|l|c|c|}
\hline Country & No. M\&A & Year of the M\&A \\
\hline Albania & 1 & 2008 \\
\hline Austria & 1 & 2010 \\
\hline Bosnia and Herzegovina & 1 & 2008 \\
\hline Finland & 1 & 2010 \\
\hline Germany & 4 & $2009,2010,2014$ \\
\hline Greece & 3 & 2012,2015 \\
\hline Netherlands & 1 & 2010 \\
\hline Poland & 2 & 2013,2014 \\
\hline Turkey & 2 & 2009,2011 \\
\hline United Kingdom & 1 & 2009 \\
\hline
\end{tabular}

Note: These M\&A are done within the country. 
Bashkim Nurboja, Marko Košak • Cost efficiency and risk as determinants of market...

Appendix 5: List of countries

\begin{tabular}{|c|c|c|c|}
\hline & Country & $\begin{array}{c}\text { European developed } \\
\text { countries }\end{array}$ & Transition Countries \\
\hline 1 & ALBANIA & 0 & 1 \\
\hline 2 & AUSTRIA & 1 & 0 \\
\hline 3 & BELGIUM & 1 & 0 \\
\hline 4 & BOSNIA AND HERZEGOVINA & 0 & 1 \\
\hline 5 & BULGARIA & 0 & 1 \\
\hline 6 & CROATIA & 0 & 1 \\
\hline 7 & CYPRUS & 1 & 0 \\
\hline 8 & CZECH REPUBLIC & 0 & 1 \\
\hline 9 & DENMARK & 1 & 0 \\
\hline 10 & FINLAND & 1 & 0 \\
\hline 11 & FRANCE & 1 & 0 \\
\hline 12 & GERMANY & 1 & 0 \\
\hline 13 & GREECE & 1 & 0 \\
\hline 14 & HUNGARY & 0 & 1 \\
\hline 15 & ICELAND & 1 & 0 \\
\hline 16 & IRELAND & 1 & 0 \\
\hline 17 & ITALY & 1 & 0 \\
\hline 18 & KOSOVO & 0 & 1 \\
\hline 19 & LATVIA & 0 & 1 \\
\hline 20 & LITHUANIA & 0 & 1 \\
\hline 21 & MACEDONIA (FYROM) & 0 & 1 \\
\hline 22 & MONTENEGRO & 0 & 1 \\
\hline 23 & NETHERLANDS & 1 & 0 \\
\hline 24 & NORWAY & 1 & 0 \\
\hline 25 & POLAND & 0 & 1 \\
\hline 26 & PORTUGAL & 1 & 0 \\
\hline 27 & REPUBLIC OF MOLDOVA & 0 & 1 \\
\hline 28 & ROMANIA & 0 & 1 \\
\hline 29 & SERBIA & 0 & 1 \\
\hline 30 & \begin{tabular}{|l|} 
SLOVAKIA \\
\end{tabular} & 0 & 1 \\
\hline 31 & SLOVENIA & 0 & 1 \\
\hline 32 & SPAIN & 1 & 0 \\
\hline 33 & SWEDEN & 1 & 0 \\
\hline 34 & SWITZERLAND & 1 & 0 \\
\hline 35 & TURKEY & 1 & 0 \\
\hline \multirow[t]{3}{*}{36} & UNITED KINGDOM & 1 & 0 \\
\hline & European developed countries & 19 & \\
\hline & Transition countries & & 17 \\
\hline
\end{tabular}

Note: When we compare transition countries with European developed countries we use as benchmark European developed countries. 